THE INDUSTRIAL INSTITUTE FOR ECONOMIC AND SOCIAL RESEARCH

WORKING PAPER No. 459, 1996

\title{
UTILIZATION OF R\&D RESULTS IN THE HOME AND FOREIGN PLANTS OF MULTINATIONALS
}

BY GUNNAR FORS 


\title{
UTILIZATION OF R\&D RESULTS IN THE HOME AND FOREIGN PLANTS OF MULTINATIONALS
}

\author{
Gunnar Fors* \\ The Industrial Institute for Economic and Social Research (IUI) \\ Box 5501, S-114 85 Stockholm, Sweden \\ Fax: + 46-8-661 7969, e-mail: gunnarf@iui.se
}

April 1996

Abstract - This paper analyzes the utilization of R\&D results in the home and foreign plants of Swedish multinational enterprises (MNEs). The empirical findings indicate that the firms' R\&D undertaken in the home country is used as an input in both the home and foreign plants of the MNEs. Around four-fifths of the gain in value-added attributed to home R\&D was realized in the MNEs' home plants, while the remaining fifth benefitted the foreign plants. Considering that the foreign plants on average accounted for a third of the MNEs' overall output, the foreign share of the gain was substantial. R\&D undertaken in foreign affiliates does not appear to be used as an input in the firms' home plants.

JEL Classification: O32, F23

Keywords: R\&D, multinationals, home and foreign plants

\footnotetext{
*Magnus Blomström, Ari Kokko and Mario Zejan, Stockholm School of Economics, and Pontus Braunerhjelm, Erik Mellander and Roger Svensson, IUI, are thanked for constructive comments. Valuable suggestions were also received from participants at the EARIE-conference, France, September 1995, and at seminars held at the Stockholm School of Economics and IUI. Support from UNCTAD to undertake this study is gratefully acknowledged.
} 


\section{Introduction}

The generation of new technologies is to a large extent dominated by multinational enterprises (MNEs). For example, $83 \%$ of aggregate Swedish industrial R\&D was attributed to Swedish MNEs in 1990 (Fors and Svensson, 1994), and the corresponding figure for US multinationals was around $80 \%$ in 1982 (Dunning, 1988). Unlike non-multinational firms, MNEs can exploit the fruits of their R\&D in production plants at home as well as abroad. Technological knowledge is to some extent a public good within the MNE, and can also be utilized in foreign affiliates.

The debate in several countries has revealed worries that the MNEs' exports of technology to foreign affiliates contribute to a de-industrialization or at least an erosion of the technological advantages of the home country. In the case of Sweden it has been argued that the $R \& D$ content of Swedish production is low, despite a national $R \& D$ intensity that ranks among the highest in the world (Blomström and Kokko, 1994). The R\&D content in Swedish exports also appears to be low compared to what could be expected from the high R\&D intensity (Lundberg, 1988, and Hansson and Lundberg, 1995). These findings may be an indication that the fruits of $R \& D$ efforts in Sweden have been utilized in foreign affiliates to a large extent.

The purpose of this paper is to analyze where the technology generated by R\&D performed by the Swedish MNEs is used. In the first part of the analysis, we study how the output gains from R\&D undertaken in Sweden are divided between the MNEs' plants at home and abroad. Thereafter, we examine the impact of $R \& D$ performed in foreign affiliates on the plants in Sweden and abroad.

Earlier studies have not attempted to measure the distribution of the gains from R\&D between plants in the home country and plants located abroad, although several authors have 
discussed these issues at a more general level (see e.g., Mansfield and Romeo, 1980, Globerman, 1994, and Blomström, 1990). There are numerous econometric studies estimating the returns to R\&D at the firm level (for a survey see Mairesse and Sassenou, 1991), but these have typically not taken into account the impact on foreign affiliates, nor the possible effects of R\&D undertaken in foreign affiliates on the home plants. ${ }^{1}$ Fors (1995) analyzes the extent and the determinants of technology transfer from Swedish parent companies to foreign affiliates at a more detailed level, but does not examine the distribution of gains attributed to home R\&D.

The paper is organized as follows: In section II, earlier studies on R\&D by multinationals are briefly reviewed. The econometric model is derived in section III, and the data material presented in section IV. Empirical results are provided in section V, and the final section concludes.

\section{R\&D by multinationals}

According to the transaction cost theory, the rationale for the existence of the multinational enterprise lies in the international utilization of intangible assets, such as technology, to avoid the market failures associated with such assets. Technological knowledge should therefore be transferred throughout the MNE (Caves, 1996). We expect that technology generated by R\&D activities will be used as an input in the multinationals' plants located at home as well as abroad.

It is generally argued that the direction of technology transfer is from the MNEs' home

\footnotetext{
${ }^{1}$ Mansfield (1984) is an exception. Lack of data on overseas R\&D, on either the firm or industry level, provides one plausible explanation. Though many industrial firms do not perform any R\&D outside their home country, still, the major part of aggregate industrial R\&D is undertaken by MNEs, of which many do perform a substantial amount of $R \& D$ abroad.
} 
country units to their foreign affiliates. Two empirical observations support this view. First, we know that R\&D expenditures are concentrated to the MNEs' home country. ${ }^{2}$ Second, it is noted that home $R \& D$ is more basic and long-term in character, compared to $R \& D$ undertaken in foreign affiliates, which is largely oriented towards adaptation (Behrman and Fischer 1980). ${ }^{3}$ Using data on affiliates of Swedish MNEs, Fors (1995) finds that home R\&D is positively related to productivity growth in foreign affiliates.

Whether there is any impact of R\&D performed in the foreign affiliates on the home operations is less obvious. To the best of my knowledge, the only study explicitly analyzing such effects is Mansfield (1984), which considered a small sample of US multinationals (fifteen firms in the chemical and petroleum sector). ${ }^{4}$ Evidence was found for positive effects of both home R\&D and R\&D performed abroad on plants located in the US. In the same study, Mansfield also presents figures for 29 foreign laboratories of US firms, indicating that on average, $40 \%$ of these laboratories' $R \& D$ was related to technologies that were transferred to the United States. Furthermore, Behrman and Fischer (1980) suggest on the basis of case studies that MNEs that undertake R\&D in foreign countries will gain easier access to foreign knowledge, which in turn can be transferred back to the home plants.

On the other hand, if $R \& D$ in foreign affiliates is predominately directed towards adaptation of the MNEs' technology to local conditions and regulations, little effect on the

\footnotetext{
${ }^{2}$ Although, an increased share of R\&D is being undertaken in foreign affiliates. Around $18 \%$ of the Swedish MNEs' R\&D was located abroad in 1990, as compared with 7\% in 1965 (Fors and Svensson, 1994).

${ }^{3}$ Considering averages for a sample of 26 Swedish MNEs in 1978 that undertook R\&D both at home and abroad, we note for home R\&D that $10 \%$ of $R \& D$ expenditures were directed towards "long term (basic) research", $48 \%$ for "new products and processes", and $42 \%$ for "improvement of existing products and processes". The corresponding figures for these firms' foreign R\&D were $2 \%, 44 \%$ and $54 \%$, respectively. These figures are taken from the database used in the empirical analysis in this paper.

${ }^{4}$ The R\&D data used by Mansfield was from the mid-1960s, while the corresponding productivity data covered the period 1960-76. Accordingly, the two data sets are not strictly confirmable, since R\&D expenditures should be related to productivity changes in subsequent periods.
} 
home operations is to be expected. ${ }^{5}$ Håkanson and Nobel (1993), studying Swedish MNEs find that adaptation of home technology on average accounts for $32 \%$, and adaptation to local regulations and political factors for $34 \%$, of the $R \& D$ expenditures in the foreign affiliates. Econometric analysis of foreign affiliates by Fors (1995) suggests that affiliate R\&D enhances exploitation of the technology created at home.

Adverse effects on home plants could be possible if the establishment of foreign R\&D units speeds up the diffusion of a MNE's knowledge assets to competitors. Mansfield et al., (1982) found that technology transfer in process industries accelerated the imitation by foreign firms, while this was not the case in other industries. ${ }^{6}$

To sum up, the firms' R\&D performed in the home country is expected to be used as an input in both the MNEs' home and foreign plants, while it is less obvious whether R\&D performed in the foreign affiliates will be used as an input in home plants. It remains an empirical question to evaluate this effect; however, it is expected that R\&D in the foreign affiliates will have a positive effect on the affiliates undertaking the $R \& D$ in question. In the next section a model is set up to test for these effects, and to allow for a quantitative assessment of the distribution of the output gains attributed to the R\&D undertaken at home between the MNE's home and foreign plants, respectively.

\section{Econometric specification}

It is assumed that the production technologies of firm $i$ 's home and foreign plants can both

\footnotetext{
'Such R\&D can be regarded as a "transfer cost" relating to international application of the firms' home technology (Teece 1977).

${ }^{6}$ It has also been suggested that R\&D in foreign affiliates may lead to a "hollowing out" of home R\&D. Norgren (1992) investigated a number of product areas in Swedish firms within the engineering sector and found that an expansion in affiliate $R \& D$ in general implied a subsequent specialization and narrowing of technological competence in the firms' Swedish R\&D departments.
} 
be represented by Cobb-Douglas functions. For notational simplicity, I will begin by making no distinction between the two production functions. Hence, in time $t$ the output of the $i:$ th firm is given as

$$
Q_{i t}=\phi e^{\lambda t} C_{i t}^{\alpha} L_{i t}^{\beta}\left(K_{H}\right)_{i t}^{\gamma_{H}}\left(K_{F}\right)_{i t}^{\gamma_{F}} e^{\varepsilon_{i t}},
$$

where $Q$ is output, $\Phi$ is a constant, $\lambda$ is the rate of disembodied technical change, ${ }^{7} C$ is the stock of physical capital, $L$ is labor input, $K_{H}$ is the knowledge stock generated by R\&D activities in the home country, and $K_{F}$ is the corresponding knowledge stock generated by R\&D in foreign affiliates. ${ }^{8}$ The elasticities $\alpha, \beta, \gamma_{H}$ and $\gamma_{F}$ relate to the four factors of production, and $\varepsilon$ is a random error term. Subscript $H$ denotes "home" and $F$ "foreign." "Home" is the sum of the MNE's operations in the home country, i.e. parent company plus units controlled by the MNE located in Sweden. "Foreign" is the aggregate of the MNE's plants located in different foreign countries.

It is hence assumed that $K_{H}$ and $K_{F}$ are available for use as inputs throughout the MNE. ${ }^{9}$ The conventional inputs $C$ and $L$, on the other hand, are tied to their location, e.g. home's labor is only used as a factor of production in the home plants. Rewriting (1) in log form, and taking first differences, we obtain

\footnotetext{
${ }^{7}$ As a matter of interpretation, it should be noted that this model constitutes an attempt to explain part of the "Solow residual" by means of resources spent on R\&D. Thus, $\lambda$ measures the R\&D-corrected Solow residual.

${ }^{8}$ This is the standard modelling approach when considering R\&D capital as an input factor (c.f. Griliches 1979). The extension here is that overall R\&D capital is decomposed into a home and a foreign component, or rather that the foreign component is added.

${ }^{9}$ The Cobb-Douglas specification (1) implies that the two kinds of knowledge stocks are assumed to be substitutes with an elasticity of substitution equal to one. If $R \& D$ in foreign affiliates is aimed at adaptation of home technologies for local use, as discussed above, a complementary relationship would be possible between the two stocks in the foreign plants. However, modelling the stocks interactively in the foreign production function (3F) below, does not produce any empirical results suggesting complementarity. We therefore maintain the simple Cobb-Douglas framework.
} 


$$
\Delta q_{i t}=\lambda+\alpha \Delta c_{i t}+\beta \Delta l_{i t}+\gamma_{H} \Delta\left(k_{H}\right)_{i t}+\gamma_{F} \Delta\left(k_{F}\right)_{i t}+\Delta \varepsilon_{i t}
$$

with lower case letters denoting logs, and where

$$
\Delta\left(k_{s}\right)_{i t}=\left(k_{s}\right)_{i t}-\left(k_{s}\right)_{i t-1}=\log \left(\frac{\left(K_{s}\right)_{i t}}{\left(K_{s}\right)_{i t-1}}\right), s=H, F
$$

which is approximately equal to $\left(K_{i t}-K_{i t-1}\right) / K_{i t-1}$ or $(\Delta K) / K_{i n-1}$. Since data on knowledge stocks, $K$, are not directly available, and in view of the obstacles associated with the construction of reliable knowledge stocks from flow data (Griliches 1979), the production function is transformed to enable utilization of data on R\&D expenditures. The terms containing $k_{H}$ and $k_{F}$ in (2) are rewritten in the following way,

$$
\gamma_{s} \Delta k_{s}=\left(\frac{\partial Q}{\partial K_{s}} \frac{K_{s}}{Q}\right) \Delta k_{s} \approx\left(\frac{\partial Q}{\partial K_{s}} \frac{K_{s}}{Q}\right)\left(\frac{\Delta K_{s}}{K_{s}}\right) \approx\left(\frac{\partial Q}{\partial K_{s}}\right)\left(\frac{R_{s}}{Q}\right) \equiv \varrho_{s}\left(\frac{R_{s}}{Q}\right), \quad s=H, F
$$

where $R$ is the R\&D expenditures in one year, $(R / Q)$ the corresponding R\&D intensity that year and $\varrho$ the rate of return on R\&D (subscripts for firm and time are left out for notational simplicity). Hence, it is assumed that the depreciation of $K$ is negligible, and that $R$ approximates the flow $\Delta K$. The approach follows that of Griliches (1980). ${ }^{10}$

In the empirical implementation, the $R \& D$ intensity is measured in $t-1$ as suggested by e.g. Scherer (1982), that is, at the beginning of $\Delta$, the period $[(t-1)-t]$. Moving from a stock, $K$, to a flow, $R$, measure of knowledge, we can thus rewrite (2) to

\footnotetext{
${ }^{10}$ For a survey of firm-level studies using this method, see Mairesse and Sassenou (1991).
} 


$$
\Delta q_{i t}=\lambda+\alpha \Delta c_{i t}+\beta \Delta l_{i t}+\varrho_{H}\left(\frac{R_{H}}{Q}\right)_{i t-1}+\varrho_{F}\left(\frac{R_{F}}{Q}\right)_{i t-1}+\eta_{i t},
$$

where $\varrho_{H}$ and $\varrho_{F}$ are the rates of return on the R\&D performed in the home country and in the foreign affiliates, respectively, and $\eta_{i t}$ is the new random error term. Estimation of (3) by ordinary least squares (OLS) is undertaken separately for the home and foreign plants, according to equations (3H) and (3F) below. ${ }^{11}$ Hence, for MNE $i$ 's home plants,

$$
\Delta q_{H i t}=\lambda_{H}+\alpha_{H} \Delta c_{H i t}+\beta_{H} \Delta l_{H i t}+\varrho_{H H}\left(\frac{R_{H}}{Q_{H}}\right)_{i t-1}+\varrho_{F H}\left(\frac{R_{F}}{Q_{H}}\right)_{i t-1}+\eta_{H i t}
$$

and for MNE $i$ 's foreign plants,

$$
\Delta q_{F i t}=\lambda_{F}+\alpha_{F} \Delta c_{F i t}+\beta_{F} \Delta l_{F i t}+\varrho_{H F}\left(\frac{R_{H}}{Q_{F}}\right)_{i t-1}+\varrho_{F F}\left(\frac{R_{F}}{Q_{F}}\right)_{i t-1}+\eta_{F i t} .
$$

In the case of the home and foreign plants' "own" R\&D, $\varrho_{H H}$ and $\varrho_{F F}$ are the rates of return on R\&D, net of costs, since the costs of capital and labor used in the R\&D are already accounted for in the production function (Griliches 1980). ${ }^{12}$ For $\varrho_{F H}$ and $\varrho_{H F}$ the interpretation is net of costs as well, since the explicit cost of the R\&D is external to $H$ and $F$, respectively. A description of the variables is provided in Table 1.

\footnotetext{
"In addition to the OLS-analysis, "Seemingly Unrelated Regressions"analysis is also undertaken, since the residuals of the two equations $(3 \mathrm{H})$ and $(3 \mathrm{~F})$ for company $i$, may be dependent on each other.

${ }^{12}$ It was not possible in the present data set to separate out the share of capital and labor input that was attributed to $R \& D$. The resulting "double-counting" of the inputs related to $R \& D$, however, does not pose a problem if the rate of return is interpreted as "excess rate of return" (Schankerman 1981). According to Verspagen (1995) the difference between estimation results based on corrected and uncorrected data, with respect to the double-counting, is limited.
} 
TABLE 1. DESCRIPTION OF VARIABLES

\begin{tabular}{|c|c|}
\hline Variable & Description \\
\hline$\Delta q_{H}$ & $\begin{array}{l}\text { Average annual growth rate in output (log form) for home plants. Output is measured } \\
\text { as value-added (value-added=wagestoperatingincome before depreciation and financial } \\
\text { items). Value-added is expressed in } 1990 \text { SEK by use of Swedish producer price } \\
\text { indices for the different industries as below. }\end{array}$ \\
\hline$\Delta q_{F}$ & Average annual growth rate in output for foreign plants (defined as above) \\
\hline$\Delta c_{H}$ & $\begin{array}{l}\text { Average annual growth rate in physical capital (log form) for home plants. Physical } \\
\text { capital is measured as book value of equipment, machinery and property. Physical } \\
\text { capital is expressed in } 1990 \text { SEK by use of Swedish capital price indices for the } \\
\text { different industries as below. }\end{array}$ \\
\hline$\Delta c_{F}$ & Average annual growth rate in physical capital for foreign plants (defined as above). \\
\hline$\Delta l_{H}$ & $\begin{array}{l}\text { Average annual growth rate in labor input (log form) in home plants. Labor input is } \\
\text { measured as average number of employees during the year in question. }\end{array}$ \\
\hline$\Delta l_{F}$ & Average annual growth rate in labor input in foreign plants (defined as above). \\
\hline$R_{H} / Q_{H}$ & $\begin{array}{l}\text { Home R\&D divided by home value-added in the beginning of } \Delta \text {. Based on nominal } \\
\text { SEK. }\end{array}$ \\
\hline$R_{p} / Q_{H}$ & $\begin{array}{l}\text { Foreign affiliate R\&D divided by home value-added in the beginning of } \Delta \text {. Based on } \\
\text { nominal SEK. }\end{array}$ \\
\hline$R_{H} / Q_{F}$ & $\begin{array}{l}\text { Home R\&D divided by foreign affiliate value-added in the beginning of } \Delta . \text { Based on } \\
\text { nominal SEK. }\end{array}$ \\
\hline$R_{p} / Q_{F}$ & $\begin{array}{l}\text { Foreign affiliate R\&D divided by foreign affiliate value-added in the beginning of } \Delta \text {. } \\
\text { Based on nominal SEK. }\end{array}$ \\
\hline $\begin{array}{l}\text { Industry } \\
\text { dummies }\end{array}$ & $\begin{array}{l}\text { Food, beverages \& tobacco } \\
\text { Textiles, clothing \& leather } \\
\text { Pulp \& paper } \\
\text { Paper products \& printing } \\
\text { Chemicals } \\
\text { Iron \& steel } \\
\text { Metal products (reference industry in regressions) } \\
\text { Non-electrical machinery } \\
\text { Electrical machinery } \\
\text { Transport equipment }\end{array}$ \\
\hline $\begin{array}{l}\text { Period } \\
\text { dummies }\end{array}$ & $\begin{array}{l}1965-70 \\
1970-74 \\
1974-78 \\
1986-90 \text { (reference period in regressions) }\end{array}$ \\
\hline
\end{tabular}

Sources: All data from the IUI database on Swedish MNEs, except for producer price and capital price indices, which are taken from Statistics Sweden (1991). 


\section{Data}

The data set used in the estimations has been collected in 1965, 1970,1974, 1978, 1986 and 1990 by The Industrial Institute for Economic and Social Research (IUI), Sweden. The survey is directed to all Swedish MNEs in the manufacturing sector that have more than 50 employees and at least one majority-owned production affiliate abroad. The response frequency has exceeded 90 percent over the years.

In this study, data on 121 Swedish MNEs were pooled over four separate time periods: $1965-70,1970-74,1974-78$ and 1986-90. The fact that the periods are not of equal length is adjusted for by defining the $\Delta$-variables as the average annual growth rate over the period in question. Of the 121 separate firms considered, 11 occurred all four time periods in the sample, 22 firms in three periods, 25 in two periods, and 63 in one period. This yielded an overall pooled cross-section time-series sample of 223 observations. ${ }^{13}$ Out of the sample of 223 observations, 75 recorded R\&D both in Sweden and abroad, 107 only in Sweden, 3 only abroad, and the remaining 38 recorded no R\&D at all. ${ }^{14}$

The partial panel characteristic of the data set is not taken into account in the present analysis for several reasons. First, more than half of the firms are only observed during one period, while as few as 11 firms are observed all four periods. A priori it can therefore be expected that a panel approach would not contribute significantly to the analysis. Second, looking at the estimation results reported below, we find that the residuals for firms observed

\footnotetext{
${ }^{13}$ The observations were distributed across time periods as follows: 1965-70 (23\%), 1970-74 (26\%), 1974-78 (29\%) and $1986-90(22 \%)$.

${ }^{14}$ The industry distribution of the 223 observations was as follows; Food,beverages \& tobacco (4\%), Textiles, clothing \& leather (8\%), Pulp \& paper (10\%), Paper products \& printing (4\%), Chemicals $(19 \%)$, Iron \& steel (7\%), Metal products (12\%), Non-electrical machinery (13\%), Electrical machinery (6\%), Transport equipment $(7 \%)$, other industries (5\%) and mixed industry classification (4\%).
} 
in more than one period do not exhibit a systematic pattern. ${ }^{15}$ The most intuitive reason for this finding is that the use of four/five-year period averages in the dependent variable reduces the probability that firms' residuals are correlated over time. The autocorrelation problem would, of course, be more prominent in the context of yearly data.

We assume that the R\&D intensity at the beginning of a period has an effect on the annual average growth rate of output over a four/five-year period. For example, the R\&D intensity in 1965 is related to growth in output over the period 1965-70. According to the notation above, the R\&D intensity in $t-1$ is related to growth in output over the period $\Delta$ (i.e. $t-1$ to $t$ ). This lag structure is consistent with earlier econometric studies on industrial R\&D. Branch (1974) found that the effect of $R \& D$ on productivity peaked after two years, which falls roughly in the middle of the period-length used in the present paper. Ravenscraft and Scherer (1982) suggest four to six years when analyzing R\&D and profits.

The variables $\Delta q$ and $\Delta c$ are expressed in constant, 1990 SEK, for both Swedish and foreign plants, by use of Swedish producer price indices and capital indices, respectively, for each of the ten different manufacturing industries included (taken from Statistics Sweden, 1991). The R\&D intensities $(R / Q: \mathrm{s})$ are based on nominal SEK for both Swedish and foreign plants. Descriptive statistics are provided in Table A1 in the Appendix.

\section{Empirical results}

Table 2 reports the results from OLS analysis of the home plants. The estimated rate of return of the MNEs' home R\&D in their home plants equals 0.13 , and is significantly different from zero at the $5 \%$ level using a two tailed t-test. Analysis of the smaller sub-sample of MNEs

\footnotetext{
${ }^{15}$ For example, out of the 33 firms observed for either three or four periods, only four firms had residuals of the same sign in all periods. This holds both for the estimation of the firms' home and foreign production function, i.e. equations $(3 \mathrm{H})$ and $(3 \mathrm{~F})$.
} 
undertaking $\mathrm{R} \& \mathrm{D}$ abroad yields a rate of return ranging between 0.11 and 0.13 , depending on the specification. Estimation of equations $(3 \mathrm{H})$ and $(3 \mathrm{~F})$ as "seemingly unrelated regressions" (SUR) produces similar results.

This rate of return of R\&D is in line with other studies using the same production function framework, analyzing the effect of firms' home R\&D on their home plants. The survey by Mairesse and Sassenou (1991) reports, for example, rates of returns in the range of $0.07-0.27$ for US chemical firms, and $0.11-0.22$ for Japanese manufacturing firms. Verspagen (1995) reports a rate of return estimate of 0.13 from a cross-country regression, and the study by Mansfield (1984) mentioned earlier finds the rate of return to be around 0.19 for US multinationals.

Analyses of separate samples over time indicate that the rate of return on the MNEs' home R\&D in their home plants has increased, from around 0.11 in $1965-74$ to 0.16 in $1974-$ 90. ${ }^{16}$ An additional result is that the impact of $R \& D$ appears to be stronger in engineering industries, where the rate of return equals 0.34 (using 1965-90 data), compared with other industries in manufacturing. ${ }^{17}$

In order to assess the distribution of the output gains attributed to the firms' home $R \& D$ between home and foreign plants, we also have to examine the impact of home $R \& D$ in foreign plants. This has been investigated in greater detail at the affiliate level in Fors (1995), but the objective in the present study is to analyze the effect of home R\&D on the MNEs' overall foreign operations, and compare this effect with the impact of home R\&D on home operations.

\footnotetext{
${ }^{16}$ Analysis of each of the four time periods separately produced no significant results. "1965-74" consists of the observations obtained when pooling 1965-70 and 1970-74 data, while "1974-90" consists of the observations from $1974-78$ and $1986-90$.
}

${ }^{17}$ The Engineering industry includes: metal products, non-electrical machinery, and electrical machinery. 
TABLE 2. OLS-REGRESSION RESULTS. HOME PLANTS (EQUATION 3H) DEPENDENT VARIABLE: ANNUAL GROWTH RATE IN OUTPUT

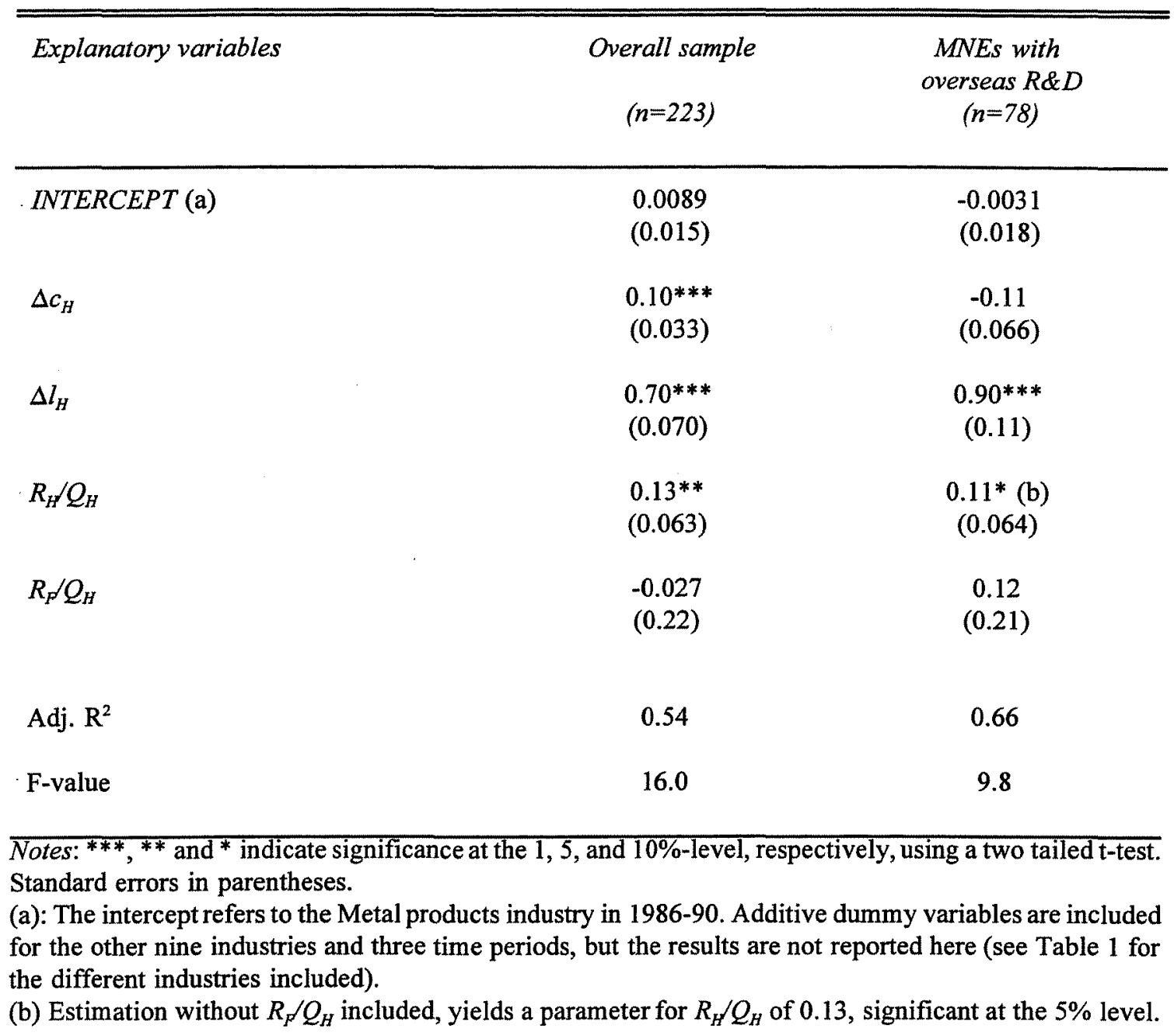


As seen from Table 3, the rate of return on home R\&D in the MNEs' foreign plants equals 0.0056 , and is significant at the $10 \%$ level. ${ }^{18}$ The results from SUR estimations are similar. We interpret a positive parameter as a sign that R\&D-generated knowledge is transferred from home to foreign plants.

The estimated rate of return is, however, not directly comparable with the above figures regarding home $R \& D$ in home plants, or other studies. The reason is that $R \& D$ undertaken in one unit (home plants) is modelled in another unit's (foreign plants) production function. To overcome this problem, I calculate the numerical effect of home R\&D in foreign plants by multiplying the estimated parameter with the mean of the corresponding variable:

$$
\hat{\varrho}_{H F}\left(\frac{\bar{R}_{H}}{Q_{F}}\right)_{t-1} x 100
$$

This computation indicates that around 0.4 percentage points of the annual growth rate in output in foreign plants can be attributed to the MNEs' home R\&D. This can be compared to an impact of 0.80 percentage points by the firms' home R\&D in home plants.

\section{Distribution of gains between home and foreign plants}

Having assessed the separate effects of the firms' home R\&D in the plants at home and abroad, we are able to calculate the distribution of the gain in value-added attributed to home R\&D between home and foreign plants. From the above figures relating to rates of return and growth in output, it appears that gains are to be found both at home and abroad.

\footnotetext{
${ }^{18}$ Estimation of equation (3F) without $R_{F} / Q_{F}$ included yields a parameter for $R_{H} / Q_{F}$ of 0.0064 , which is significant at the $5 \%$ level (see Table A2 in Appendix for the complete statistical results). Hence, a higher significance is obtained when the other R\&D variable is removed. This may imply problems of multicollinearity; however, as the parameter estimates between the versions of (3F) are rather stable, this should not be a major problem. Moreover, the two R\&D variables are only weakly correlated (Pearson correlation coefficient equals $0.18)$.
} 
TABLE 3. OLS-REGRESSION RESULTS. FOREIGN PLANTS (EQUATION 3F) DEPENDENT VARIABLE: ANNUAL GROWTH RATE IN OUTPUT

\begin{tabular}{|c|c|c|}
\hline Explanatory variables & $\begin{array}{l}\text { Overall sample } \\
\qquad(n=223)\end{array}$ & $\begin{array}{c}\text { MNEs with } \\
\text { overseas } R \& D \\
(n=78)\end{array}$ \\
\hline INTERCEPT (a) & $\begin{array}{l}0.0072 \\
(0.022)\end{array}$ & $\begin{array}{l}-0.0032 \\
(0.028)\end{array}$ \\
\hline$\Delta c_{F}$ & $\begin{array}{c}0.062 \\
(0.042)\end{array}$ & $\begin{array}{c}0.11 \\
(0.095)\end{array}$ \\
\hline$\Delta l_{F}$ & $\begin{array}{c}0.80^{* * *} \\
(0.050)\end{array}$ & $\begin{array}{l}0.72^{* * *} \\
(0.086)\end{array}$ \\
\hline$R_{H} / Q_{F}$ & $\begin{array}{c}0.0056^{*}(\mathrm{~b}) \\
(0.0029)\end{array}$ & $\begin{array}{c}0.0026 \\
(0.0029)\end{array}$ \\
\hline$R_{F} / Q_{F}$ & $\begin{array}{c}0.13^{*} \\
(0.077)\end{array}$ & $\begin{array}{l}0.21 * * * \\
(0.076)\end{array}$ \\
\hline Adj. $R^{2}$ & 0.73 & 0.74 \\
\hline F-value & 35.6 & 13.6 \\
\hline \multicolumn{3}{|c|}{$\begin{array}{l}\text { Notes: }{ }^{* * *} \text { and }{ }^{*} \text { indicate significance at the } 1 \text { and } 10 \% \text { level, respectively, using a two tailed t-test. } \\
\text { Standard errors in parentheses. } \\
\text { (a): The intercept refers to the Metal products industry in 1986-90. Additive dummy variables are included } \\
\text { for the other nine industries and three time periods, but the results are not reported here (see Table } 1 \text { for } \\
\text { the different industries included). } \\
\text { (b): Estimation without } R_{P} / Q_{F} \text { included, yields a parameter for } R_{H} / Q_{F} \text { of } 0.0064 \text {, significant at the } 5 \% \\
\text { level (see Table A2 in Appendix for the complete statistical results). }\end{array}$} \\
\hline
\end{tabular}


The volume gains for the home and foreign plants, respectively, are calculated as follows: the percentage point contribution of home $R \& D$ to average annual growth in output (over the period $t-1$ to $t$ ), multiplied by the average "initial value" of output in $t-1 \cdot{ }^{19}$ Hence, the gain for the home plants is computed according to:

$$
\left[\hat{\varrho}_{H H}\left(\frac{\bar{R}_{H}}{Q_{H}}\right)_{t-1} x 100\right] \bar{Q}_{H t-1},
$$

and the gain for the foreign plants according to:

$$
\left[\hat{\varrho}_{H F}\left(\frac{\bar{R}_{H}}{Q_{F}}\right)_{t-1} x 100\right] \bar{Q}_{F t-1} .
$$

These numerical computations are performed around estimated parameters and corresponding sample means, as in the previous sub-section. The gains in the home and foreign plants are then added to a total figure, and the home and foreign shares are simply calculated as the share of that total. Computations according to the above formulas indicate that $81 \%$ of the total gain in value-added, attributed to the MNEs' home $\mathrm{R} \& \mathrm{D}$, was realized in home plants, while the remaining $19 \%$ was realized in the firms' foreign plants.

Taking into account that the foreign plants in the sample on average accounted for $32 \%$ of the total output of the MNEs, there is no support for the assertion that a disproportionate share of the gain from the R\&D undertaken in Sweden is exploited in foreign plants. Yet, it is apparent that there are substantial flows of technology to the foreign plants from the Swedish parent companies.

When separate regressions are run for the two time periods 1965-74 and 1974-90, the share of the gain realized in foreign plants increases, from $16 \%$ in the earlier period, to $43 \%$

\footnotetext{
${ }^{19}$ The output in $t-1$ is expressed in 1990 SEK and the R\&D intensity is based on nominal SEK.
} 
in the later period. This is partly a reflection of the increased relative size of the foreign operations over time. However, even after correcting for the relative size, the gains during 1974-90 were to a disproportionately high degree realized in foreign plants. Thus, R\&D undertaken in the home operations of Swedish MNEs appears to become increasingly geared towards utilization in the MNEs' foreign plants. ${ }^{20}$

\section{$R \& D$ in foreign affiliates}

Table 2 reports a non-significant rate of return on the firms' foreign $R \& D$ in their home plants. This applies to both the overall sample and the sub-sample of MNEs undertaking R\&D abroad. Estimations with SUR instead of OLS did not alter the basic results. Separate regressions of different time periods and industries do not produce any significant results either. Thus, the findings for Swedish MNEs do not verify Mansfield's (1984) conclusion that technologies developed in foreign affiliates are systematically transferred to the home plants. ${ }^{21}$

The estimated rate of return on the foreign affiliates' own R\&D equals 0.13 , and is significant at the $10 \%$ level (Table 3), which is the same rate of return that was obtained in the estimation of home $R \& D$ in home plants. This is a comforting result: on theoretical grounds we should expect the MNE to locate its R\&D activities such that it yields the same rate of return in the home and foreign plants.

Since no signs of technology transfer from foreign affiliates to home plants could be

\footnotetext{
${ }^{20}$ Some caution should be exercised in the interpretation, since the overall sample analyzed earlier is here split in two. This implies that partly different populations of firms are included in the two sub-samples.

${ }^{21}$ Mansfield (1984) employed a similar econometric framework, but used a prior measurement of growth in total factor productivity (DTFP) from a source other than his R\&D data as dependent variable. The model estimated in the present paper has growth in output as the dependent variable. Since the rate of return interpretation with respect to R\&D is identical when using growth in output or growth in TFP, equation (3H) can be rewritten and estimated with DTFP as dependent variable. However, doing so did not change the results.
} 
found, the question arises whether there are any effects of foreign activities in general on the home plants of the Swedish MNEs. To investigate this in a very simple way, the degree of internationalization of a MNE (proxied by the share of a firm's total labor force employed abroad) was included additively in the production function [equation $(3 \mathrm{H})$ ] as a component of the disembodied technological change $\left(\lambda_{H}\right)$. The results from this regression show that the level of internationalization in the beginning of a period was not significantly associated with the average annual growth of output in the home plants. A more elaborate analysis is, of course, necessary in order to draw any conclusions on the impact of internationalization on home plants.

\section{Concluding remarks}

The estimated rate of return on Swedish multinationals' home R\&D in their home plants is positive, and in line with estimates obtained from other countries. The rate of return also appears to have increased over time. In addition to being utilized in home plants, the empirical results suggest that R\&D-generated knowledge is transferred to foreign plants.

Numerical calculations suggest that around four-fifths of the total gain in value-added attributed to the firms' home R\&D is realized in the home plants while the remaining fifth benefitted the MNEs' foreign plants. Taking into account that the foreign plants in the sample on average accounted for less than a third of the total output of the MNEs, there is no support for the assertion that a disproportionate share of the gain from the R\&D undertaken in Sweden are exploited in foreign plants, at least when considering the 1965-90 sample. Yet, it is apparent that there are substantial flows of technology to the foreign plants from the Swedish parent companies.

Analyses of separate periods give some indication that the foreign plants' share of the 
gain has increased over time. This may imply that R\&D undertaken in Sweden is becoming more oriented towards utilization in foreign plants. However, in order to sustain large-scale R\&D units at home, it is crucial for the MNEs to utilize R\&D-generated knowledge worldwide in their operations.

No significant evidence could be found for technology transfer taking place from the firms' foreign plants to their home plants. In view of the orientation of R\&D in foreign affiliates towards more adaptive work, this finding comes as no surprise. Even if some degree of technology transfer probably does take place in this direction, the positive effects are either too small to measure, or offset by negative effects, such as increased leakage of home technology. Perhaps we are also looking at foreign plants at different stages in the value-added chain. Foreign affiliates could be downstream which might imply that their R\&D is not applicable to the parent company's production.

Areas for future research along the lines of the present paper include an assessment of the impact of MNEs' foreign activity on their home operations, taking into account variables other than R\&D. In this respect it would also be valuable to analyze the impact on the home country outside the boundaries of the MNE. In addition, it would be interesting to follow up the present analysis with newer data to examine whether the utilization of Swedish $R \& D$ in foreign affiliates is increasing over time.

\section{References}

Behrman, J. N. and W. A. Fischer, 1980, Overseas R\&D Activities of Transnational Companies. Cambridge, MA: Oelgeschlager, Gunn \& Hain.

Blomström, M., 1990, "Competitiveness of Firms and Countries", in Dunning, J., B. Kogut and M. Blomström, (eds.), Globalization of Firms and the Competitiveness of Nations. Crafoord Lectures 1989. Lund: Lund University Press. 
and A. Kokko, 1994, "Home-country effects of Foreign Direct Investment: Sweden", in Globerman, S. (ed.), Canadian-Based Multinationals, The Industry Canada Research Series, Vol 4. Calgary: University of Calgary Press.

Branch, B., 1974, "Research and Development Activity and Profitability: A Distributed Lag Analysis", Journal of Political Economy, 82, No 5, pp. 999-1011.

Caves, R. E., 1996, Multinational Enterprise and Economic Analysis, second edition. Cambridge: Cambridge University Press.

Dunning, J. H., 1988, Multinationals, Technology and Competitiveness. London: Allen, Unwin, Hyman.

Addison-Wesley.

1992, Multinational Enterprises and the Global Economy. Wokingham:

Fors, G., 1995, Technology Transfer to Foreign Affiliates by Multinational Enterprises, IUI Working Paper No 456.

and R. Svensson, 1994, $R \& D$ in Swedish Multinational Corporations. Stockholm: Swedish National Board for Industrial and Technical Development.

Globerman, S., 1994, "The Public and Private Interests in Outward Direct Investment", in S. Globerman (ed.), Canadian-Based Multinationals, The Industry Canada Research Series, Vol 4. Calgary: University of Calgary Press.

Griliches, Z., 1979, "Issues in Assessing the Contribution of Research and Development to Productivity Growth", Bell Journal of Economics, Vol 10, No 1, pp. 92-116.

1980, "Returns to Research and Development Expenditures in the Private Sector", in J. W Kendrick and B. N. Vaccara (eds.), New Developments in Productivity Measurement and Analysis. Chicago and London, NBER and The University of Chicago Press.

Hansson, P. and L. Lundberg, 1995, Från basindustri till högteknologi, (From Basic Industries to High-tech). Stockholm: SNS.

Håkanson, L. and R. Nobel, 1993, "Foreign Research and Development in Swedish Multinationals", Research Policy, 22, pp. 373-96.

Lundberg, L, 1988, "Technology, Factor Proportions and Competitiveness", Scandinavian Journal of Economics, 90 (2), pp. 173-88.

Mairesse, J. and M. Sassenou, 1991, "R\&D and Productivity: A Survey of Econometric Studies at the Firm Level", Cambridge, MA: NBER Working Paper No. 3666. 
Mansfield, E., 1984, "R\&D and Innovation: Some Empirical Findings", in Z. Griliches (ed.), $R \& D$, Patents and Productivity. Chicago and London: The University of Chicago Press and NBER.

and A. Romeo, 1980, "Technology Transfer to Overseas Subsidiaries by USBased Firms", Quarterly Journal of Economics, December, pp. 737-50

and S. Wagner, 1979, "Foreign Trade and US Research and Development", Review of Economics and Statistics, Vol LXI, pp. 49-57.

M. Schwartz, D. Teece, S. Wagner and P. Brach, 1982, Technology Transfer, Productivity and Economic Policy. New York: W. W. Norton.

Norgren, L., 1992, Industriföretags FoU $i$ Sverige och utomlands (Industrial Firms' R\&D in Sweden and Overseas). Stockholm: FA-Rådet.

Ravenscraft, D. and F. M. Scherer, 1982, "The Lag Structure of Returns to Research and Development", Applied Economics, 14, pp. 603-20.

Schankerman, M., 1981, "The Effects of Double-counting and Exspensing on the Measured Returns to R\&D", Review of Economics and Statistics, LXIII, pp. 454-458.

Scherer, F. M., 1982, "Inter Industry Technology Flows and Productivity Growth", Review of Economics and Statistics, LXIV, pp. 627-34.

Statistics Sweden, 1991, Statistisk Arsbok (Statistical Yearbook for Sweden) and other material from Statistics Sweden.

Teece, D. J., 1977, "Technology Transfer by Multinational Firms: The Resource Cost of Transferring Technological Know-how", Economic Journal, Vol. 87, pp. 242-61.

Verspagen, B., 1995, "R\&D and Productivity: A Broad Cross-Section Cross-Country Look", Journal of Productivity Analysis, 6, pp. 117-35. 


\section{Appendix}

TABLE A1. MEAN VALUES OF VARIABLES

HOME AND FOREIGN PLANTS

\begin{tabular}{|c|c|c|}
\hline Variable & $\begin{array}{l}\text { Overall sample } \\
\qquad(n=223)\end{array}$ & $\begin{array}{c}\text { MNEs with overseas } R \& D \\
\qquad(n=78)\end{array}$ \\
\hline$\Delta q_{H}$ & $\begin{array}{c}0.021 \\
(0.096)\end{array}$ & $\begin{array}{c}0.016 \\
(0.087)\end{array}$ \\
\hline$\Delta c_{H}$ & $\begin{array}{l}0.030 \\
(0.16)\end{array}$ & $\begin{array}{l}0.034 \\
(0.10)\end{array}$ \\
\hline$\Delta l_{H}$ & $\begin{array}{r}-0.0040 \\
(0.077)\end{array}$ & $\begin{array}{c}-0.00018 \\
(0.065)\end{array}$ \\
\hline$R_{H} / Q_{H}$ & $\begin{array}{c}0.064 \\
(0.091)\end{array}$ & $\begin{array}{c}0.12 \\
(0.12)\end{array}$ \\
\hline$R_{P} / Q_{H}$ & $\begin{array}{c}0.019 \\
(0.025)\end{array}$ & $\begin{array}{c}0.030 \\
(0.036)\end{array}$ \\
\hline$\Delta q_{F}$ & $\begin{array}{c}0.14 \\
(0.19)\end{array}$ & $\begin{array}{c}0.13 \\
(0.16)\end{array}$ \\
\hline$\Delta c_{F}$ & $\begin{array}{c}0.11 \\
(0.22)\end{array}$ & $\begin{array}{l}0.094 \\
(0.15)\end{array}$ \\
\hline$\Delta l_{F}$ & $\begin{array}{l}0.090 \\
(0.19)\end{array}$ & $\begin{array}{l}0.092 \\
(0.17)\end{array}$ \\
\hline$R_{H} / Q_{F}$ & $\begin{array}{c}0.72 \\
(2.43)\end{array}$ & $\begin{array}{c}0.84 \\
(3.61)\end{array}$ \\
\hline$R_{F} / Q_{F}$ & $\begin{array}{c}0.025 \\
(0.091)\end{array}$ & $\begin{array}{l}0.072 \\
(0.14)\end{array}$ \\
\hline
\end{tabular}

Note: Standard deviations in parentheses. 
TABLE A2. OLS-REGRESSION RESULTS. FOREIGN PLANTS (EQ. 3F) DEPENDENT VARIABLE: ANNUAL GROWTH RATE IN OUTPUT

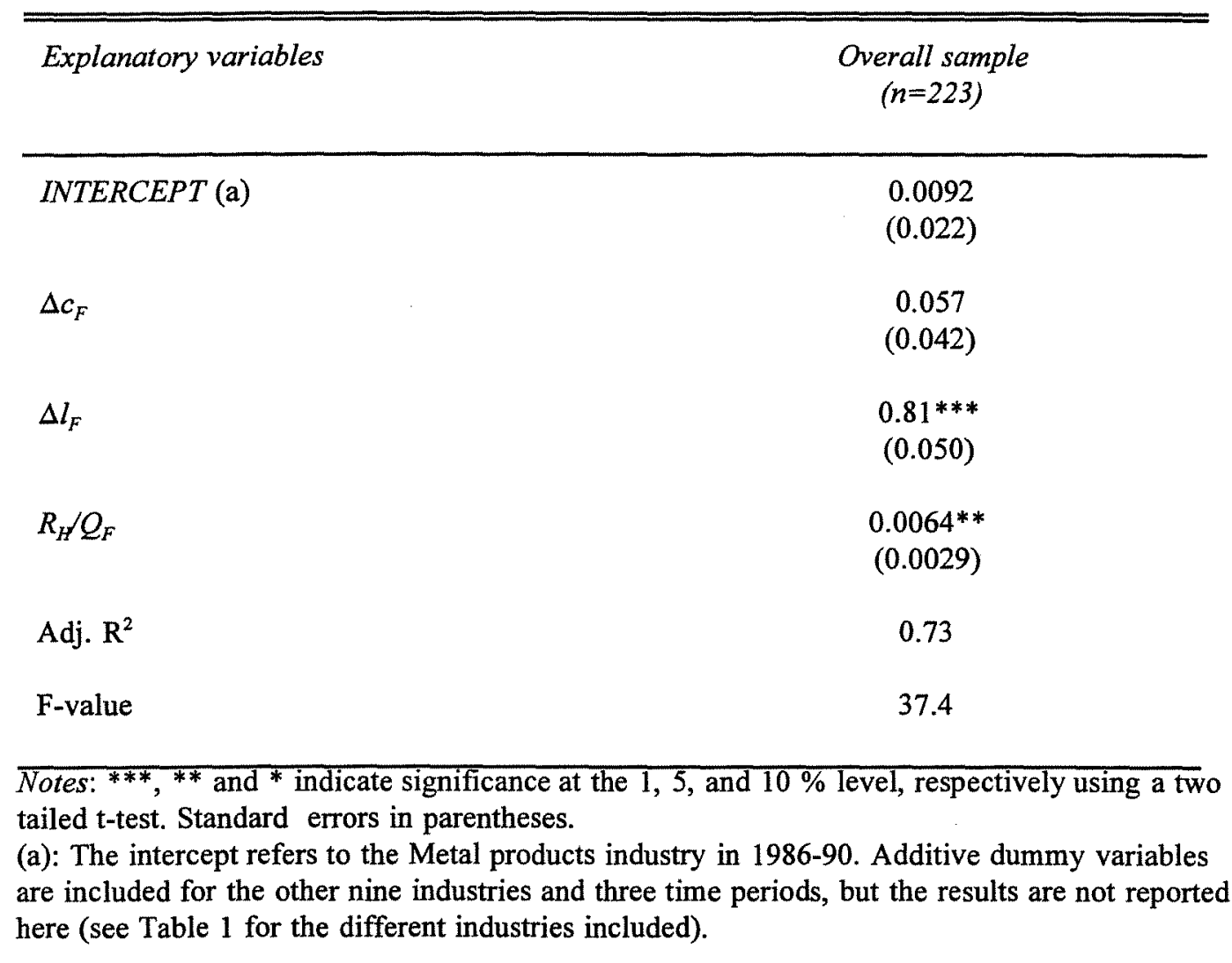

